\title{
PREPARASI CONTOH UJI PROFISIENSI UNTUK IDENTIFIKASI SENYAWA KIMIA BERBAHAYA
}

\section{PREPARATION OF SAMPLE PROFICIENCY TESTING TO IDENTIFICATION HAZARD CHEMICAL COMPOUNDS}

\author{
Evita Boes \\ Pusat Penelitian Kimia - Lembaga Ilmu Pengetahuan Indonesia \\ Jl. Sangkuriang 21/54 D Bandung 40135 \\ Email: evitaboes@yahoo.com
}

Diterima : 14 Maret 2015, Revisi : 18 April 2015, Disetujui : 06 April 2015

\begin{abstract}
ABSTRAK
Telah dibuat contoh uji profisiensi senyawasenyawa kimia berbahaya dalam contoh pelarut organik dan air untuk identifikasi senyawa-senyawa kimia berbahaya. Pada contoh ditambahkan berbagai senyawa pengganggu. Contoh pelarut organik diambil dari buangan organik (waste) yang ditambahkan dikhlorometan sebagai pelarut, undecane $100 \mu \mathrm{l} / \mathrm{mL}, \quad$ 1,2-dimethylbenzene 12 $\mu \mathrm{l} / \mathrm{mL}$, solar $100 \mu \mathrm{l} / \mathrm{mL}$ dan tributhyl phosphate $10,02 \mu \mathrm{g} / \mathrm{mL}$, sedangkan contoh air berasal dari air buangan yang ditambahkan magnesium sulfat heptahydrate $120 \mu \mathrm{g} / \mathrm{mL}$, natrium karbonat anhydrous $106 \mu \mathrm{g} / \mathrm{mL}$, natrium sulfat anhydrous $284 \mu \mathrm{g} / \mathrm{mL}$, kalsium khlorida dyhidrat $222 \mu \mathrm{g} / \mathrm{mL}$, dikhlorometan $2,5 \mu \mathrm{l} / \mathrm{mL}$, polyethylene glycol $505,4 \mu \mathrm{g} / \mathrm{mL}, 3,5$ dihydroxytoluene $10,05 \mu \mathrm{g} / \mathrm{mL}$ dan $\alpha$ methyl- $\alpha$-propyl succinimide $10,01 \mu \mathrm{g} / \mathrm{mL}$. Jenis senyawa-senyawa kimia berbahaya yang ditambahkan yaitu Bis (3-methylbutyl) ethylphosphonate $10,04 \pm 0,31 \mu \mathrm{g} / \mathrm{mL}$, Bis (2chloroethyl) methylamine 20,59 $\pm 0,14 \mu \mathrm{g} / \mathrm{mL}$ untuk contoh pelarut organik dan Pinacolyl methylphosphonate $9,80 \pm 0,18 \quad \mu \mathrm{g} / \mathrm{mL} \quad$ dan Triethanolamine $14,84 \pm 0,10 \mu \mathrm{g} / \mathrm{mL}$ untuk contoh air. Uji homogenitas dan stabilitas ditentukan secara kuantitatif menggunakan GC-FPD (P-Mode) dan GC-FID dengan kurva kalibrasi menggunakan internal standar dibutyl butylphosphonate, 2,6dimethylphenol, dibutylphosphate dan bis(2hydroxypropyl) aminoethanol dan diperoleh nilai Relative Standard Deviasi (RSD) $8,10 \%$ dan 12,40 $\mu \mathrm{g} / \mathrm{mL} \quad$ untuk Bis (3-methylbutyl) ethylphosphonate, 3,46\% dan $14,19 \mu \mathrm{g} / \mathrm{mL}$ untuk Bis (2-chloroethyl) methylamine, 2,22\% dan 11,28 $\mu \mathrm{g} / \mathrm{mL}$ untuk Pinacolyl methylphosphonate dan $2,70 \%$ dan $11,47 \mu \mathrm{g} / \mathrm{mL}$ untuk Triethanolamine. Relative Standard Deviasi yang dihasilkan adalah nilai homogenitas yang diperoleh kecil dari $20 \%$
\end{abstract}

dan stabilitas adalah tingkat degradasi yang diperoleh kecil dari $30 \%$.

Kata kunci: senyawa-senyawa kimia berbahaya, uji profisiensi, homogenitas, stabilitas, relative standar deviasi

\section{ABSTRACT}

The sample of proficiency test for hazard chemical compounds in organic and water sample has been made to identify hazard chemical compounds. Here, various matrix was added to these hazard chemical compound. The organic sample derived from organic waste added with dichloromethane as the solvent, undecane 100 $\mu \mathrm{l} / \mathrm{mL}, 1,2$-dimethylbenzene $12 \mu \mathrm{l} / \mathrm{mL}$, diesel 100 $\mu \mathrm{l} / \mathrm{mL}$ and tributhyl phosphate 10,02 $\mu \mathrm{g} / \mathrm{mL}$, whereas water sample derived from water waste added with magnesium sulfate heptahydrate 120 $\mu \mathrm{g} / \mathrm{mL}$, sodium carbonate anhydrous $106 \mu \mathrm{g} / \mathrm{mL}$, sodium sulfate anhydrous $284 \mu \mathrm{g} / \mathrm{mL}$, calsium chloride dyhidrate $222 \mu \mathrm{g} / \mathrm{mL}$, dikhloromethane 2,5 $\mathrm{\mu l} / \mathrm{mL}$, polyethylene glycol 505,4 $\mu \mathrm{g} / \mathrm{mL}, 3,5$ dihydroxytoluene $10,05 \mu \mathrm{g} / \mathrm{mL}$ and $\alpha$ methyl- $\alpha$ propyl succinimide 10,01 $\mu \mathrm{g} / \mathrm{mL}$. Hazard chemical compounds that being added are Bis (3methylbutyl) ethylphosphonate 10,04 $\pm 0,31 \mu \mathrm{g} / \mathrm{mL}$, Bis (2-chloroethyl) methylamine 20,59 $\pm 0,14 \mu \mathrm{g} / \mathrm{mL}$ for organic sample and Pinacolyl methylphosphonate $9,80 \pm 0,18 \quad \mu \mathrm{g} / \mathrm{mL}$ and Triethanolamine $14,84 \pm 0,10 \mu \mathrm{g} / \mathrm{mL}$ for water sample. Homogeneity and stability are determined quantitatively using GC-FPD (P-mode) and $G C$ FID with calibration curve using internal standard dibuty butylphosphonate, 2,6-dimethylphenol, dibutylphosphate and Bis (2-hydroxypropyl) aminoethanol with Relative Standard Deviation (RSD) 8,10 \% and 12,40 $\mu \mathrm{g} / \mathrm{mL}$ for Bis (3methylbutyl) ethylphosphonate and 3,46 \% and $14,19 \mu \mathrm{g} / \mathrm{mL}$ for Bis (2-chloroethyl) methylamine 
and $2,22 \%$ and $11,28 \mu \mathrm{g} / \mathrm{mL}$ for Pinacolyl methylphosphonate and 2,70 \% and 11,47 $\mu \mathrm{g} / \mathrm{mL}$ for Triethanolamine. Relative Standard Deviation is a homogeneity value with requirements below 20 $\%$ and stability is a degradation result which value is less than $30 \%$.

Keywords: hazard chemical compounds, proficiency test, homogeneity, stability, relative standard deviation

\section{PENDAHULUAN}

Senyawa-senyawa kimia berbahaya berdasarkan tingkat toksisitasnya dibagi kedalam beberapa kategori yaitu senyawa yang memiliki resiko tinggi, diserap oleh tubuh melalui kulit dan sistem pernapasan yang dapat memblok sel-sel saraf sehingga sistem saraf tidak berfungsi, senyawa yang diserap melalui sistem pernapasan dan tersebar keseluruh tubuh akibatnya mengurangi kemampuan darah untuk mengalirkan oksigen dan senyawa diserap oleh tubuh melalui sistem pernafasan, mata dan kulit dapat mengakibatkan terjadinya iritasi dan kerusakan pada sistem pernafasan serta mematikan sel-sel tubuh $^{(1)}$.

Dalam analisis identifikasi senyawasenyawa kimia berbahaya diperlukan laboratorium yang mempunyai kemampuan untuk pengujian identifikasi senyawa-senyawa kimia berbahaya yang dimulai dari preparasi contoh dengan berbagai teknik preparasi dan analisis dilanjutkan menggunakan instrumen pengujian kimia yang sesuai seperti metode kromatografi cairan, kromatografi gas dengan berbagai detektor yang spesifik, kromatografi cairan spektrometri massa, kromatografi gas spektrometrri massa, NMR dan metode-metode lainnya. Di Indonesia identifikasi senyawa-senyawa kimia berbahaya dilakukan oleh beberapa laboratorium pemerintahan dan swasta. Kemampuan setiap laboratorium bervariasi tergantung pada peralatan dan sumber daya manusia yang dimiliki oleh masing-masing laboratorium. Untuk dapat bersaing di era globalisasi maka data analisis yang dihasilkan oleh setiap laboratorium haruslah andal dan absah yang dapat diterima baik secara nasional, regional maupun internasional. Agar laboratorium dapat menghasilkan data yang baik, laboratorium harus meningkatkan kinerjanya dan salah satu upaya untuk meningkatkan kinerja laboratorium, dapat dilakukan melalui uji profisiensi. Dalam dokumen yang dikeluarkan oleh suatu organisasi, penilaian kinerja laboratorium dalam bentuk identifikasi senyawasenyawa kimia berbahaya pada berbagai matrik uji dengan tambahan bahan-bahan kimia lainnya sebagai pengotor dan diuji menggunakan 2 metode uji yang berbeda. Metode uji yang diutamakan adalah kromatografi baik cair maupun gas dan salah satunya harus menggunakan spektrometri massa.

Untuk menjamin kualitas suatu hasil uji dengan cara identifikasi atau supaya kualitas hasil uji mendapatkan pengakuan yang berlaku internesional salah satunya keikut sertaan dalam uji profisiensi antar laboratorium $^{(2,3)}$. Berdasarkan ISO/IEC 17043 uji profisiensi merupakan suatu cara untuk mengetahui kinerja laboratorium dengan cara uji banding antar laboratorium $^{(4)}$. Penilaian hasil uji profisiensi dinilai dalam bentuk nilai A, B, C, D dan F. Nilai A akan diperoleh apabila laboratorium peserta uji profisiensi melaporkan semua senyawa-senyawa kimia berbahaya sesuai dengan yang ditambahkan ke dalam matrik contoh, B apabila ada 1 senyawa yang ditambahkan yang tidak teridentifikasi, $\mathrm{C}$ apabila ada 2 senyawa dari yang ditambahkan tidak teridentifikasi, sedangkan D apabila ada 3 senyawa yang ditambahkan tidak teridentifikasi dan $\mathrm{F}$ adalah yang tidak teridentifikasi sama sekali ${ }^{(3,5)}$.

Suatu contoh uji profisiensi untuk identifikasi senyawa kimia berbahaya harus mempunyai matrik, bahan - bahan 
pengganggu, senyawa-senyawa kimia berbahaya yang akan diidentifikasi pada rentang konsentrasi tertentu. Senyawasenyawa kimia berbahaya murni tidak dapat menggambarkan dengan seutuhnya matrik dan pengganggu dalam contoh uji.

Contoh uji profisiensi dengan matriks pelarut organik dan air, sebelum didistribusikan kepada laboratorium peserta haruslah homogen untuk setiap senyawa-senyawa bahan kimia berbahaya sehingga laboratorium peserta menerima contoh dengan kondisi yang tidak berbeda secara significant ${ }^{(6,7)}$. Disamping homogen contoh uji profisiensi haruslah stabil secara fisika dan kimia selama proses pengujian oleh laboratorium peserta. Contoh-contoh yang disiapkan harus melalui uji homogenitas dan stabilitas. Homogenitas dapat ditentukan dari variabilitas hasil uji dalam bentuk nilai Relative Standar Deviasi yang dihasilkan dari contoh uji profisiensi yang dianalisis oleh laboratorium pembuat contoh dengan nilai keberterimannya $<20 \%$, sedangkan kriteria stabilitas dapat ditentukan dari degradasi contoh selama 1-30 hari pada temperatur $35^{\circ} \mathrm{C}$. Nilai degradasi diperoleh dari analisis secara kuantitatif dengan rentang pengukuran nilai ketidakpastian pada tingkat kepercayaan $95 \%$ dan nilai keberterimaan degradasi adalah $<30 \%{ }^{(8)}$.

Tujuan dari tulisan ini adalah untuk menjelaskan penyiapan contoh uji profisiensi untuk identifikasi senyawasenyawa kimia berbahaya, dengan matrik organik dan air yang ditambahkan bahanbahan pengganggu dan menjelaskan bagaimana menentukan penentuan uji homogenitas dan stabilitas dari contoh uji profisiensi yang dibuat.

\section{BAHAN DAN METODA}

\section{Bahan}

$\begin{array}{ccr}\text { Senyawa } & \text { Bis } & \text { (3-methylbutyl) } \\ \text { ethylphosphonate, } & \text { Bis } & \text { (2-chloroethyl) }\end{array}$

methylamine, Pinacolyl methyl phosphonate, Triethanolamine, tributhyl phosphate dan magnesium sulfat heptahydrate menggunakan produk dari Aldrich USA dan Bis (Trimethylsilil)trifluoroasetamida (BSTFA) menggunakan produk dari Supelco USA.

Dichloromethane, undecane, 1,2dimethylbenzene, natrium karbonat anhydrous, natrium sulfat anhydrous, kalsium khlorida dyhidrat, polyethylene glycol, 3,5 dihydroxytoluene, $\alpha$ methyl- $\alpha-$ propyl succinimide menggunakan produk dari Fluka. Bahan lainnya adalah solar, botol glass transparan ukuran $25 \mathrm{~mL}$ dan $50 \mathrm{~mL}$.

\section{Peralatan}

Gas Chromatography (GC) Agilent 6890 (USA) dengan Flame Photometric Detector (FPD) P Mode dan Flame Ionozation Detector (FID) dan kolom kapiler DB 5.

Gas Chromatography Mass Spectrometer (GC/MS) Agilent 6890N/Agilent 5975 Inert XL EI/CI MSD (USA) menggunakan kolom DB-5MS (30 $\mathrm{m} \times 0,25 \mathrm{~mm} \times 0,25 \mu \mathrm{m}$ ) (Agilent $\mathrm{J} \& \mathrm{~W}$ dari USA).

\section{Pemilihan jenis contoh uji profisiensi}

Contoh uji ditetapkan jenisnya yaitu contoh uji profisiensi pelarut organik dan air. Contoh dengan pelarut organik diambil dari tangki limbah organik sedangkan sampel air diambil dari tangki limbah air. Ke dalam setiap contoh baik organik dan contoh air ditambahkan bahan kimia pengganggu dan senyawa-senyawa kimia berbahaya yang diidentifikasi sebagai analit yang akan ditentukan pada pelaksanaan uji profisiensi oleh setiap laboratorium peserta. 


\section{Persiapan contoh organik}

Larutan senyawa yang diidentifikasi dibuat masing-masing yaitu Bis (3methylbutyl) ethylphosphonate $1827 \pm 56$ $\mu \mathrm{g} / \mathrm{mL}$ dan Bis (2-chloroethyl) methylamine $3167 \pm 21 \mu \mathrm{g} / \mathrm{mL} \quad$ dan senyawa kimia tributilfosfat $1055 \mu \mathrm{g} / \mathrm{mL}$ yang masing-masing dilarutkan dalam dikloromethana.

Contoh disiapkan dalam 2 buah labu takar $200 \mathrm{~mL}$ dengan masing-masing dipipet $100 \mathrm{~mL}$ limbah organik, ditambahkan $80 \mathrm{~mL}$ dikloromethana, 20 $\mu \mathrm{L}$ undecana, $2,4 \mathrm{~mL}$ 1,2dimethylbenzene, $200 \mu \mathrm{L}$ solar, 1,9 $\mathrm{mL}$ tributilfosfat, 1,1 mL senyawa Bis (3methylbutyl) ethylphosphonate dan 1,3 mL senyawa Bis (2-chloroethyl) ethylamine, ditepatkan volume hingga $200 \mathrm{~mL}$ dengan dikhloromethana dan diaduk selama 2 menit. Larutan dalam kedua labu takar tersebut dicampurkan ke dalam botol ukuran $1 \mathrm{~L}$, diaduk dan dibiarkan selama 24 jam. Uji kualitatif dilakukan dengan teknik GC-MS, GC-FID dan GC-FPD (PMode) untuk memverifikasi komposisi sebelum dimasukkan ke dalam botol masing-masing sebanyak $25 \mathrm{~mL}$ yang akan dikirim ke laboratorium peserta.

Blanko contoh organik disiapkan sebanyak 2 x $200 \mathrm{ml}$ dikhloromethana dan dianalisis menggunakan teknik yang sama yaitu GC-MS, GC-FID dan GC-FPD (PMode) untuk memverifikasi bahwa blanko atau pelarut dikloromethana yang digunakan tidak mengandung senyawa kimia yang akan diidentifikasi Bis (3methylbutyl) ethylphosphonate dan Bis (2chloroethyl) methylamine.

\section{Persiapan contoh air}

Larutan senyawa yang diidentifikasi dibuat dengan konsentrasi masing-masing Pinacolyl methylphosphonate $4168 \pm 75$ $\mu \mathrm{g} / \mathrm{mL}$ dan Triethanolamine $6317 \pm 40$ $\mu \mathrm{g} / \mathrm{mL}$ yang dilarutkan dalam asetonitril.
Bahan kimia yang lain dibuat, 3,5 dihydroxytoluene $5156 \mu \mathrm{g} / \mathrm{mL}$ dan 2(diethylamino) ethyltetrahydro- $\alpha-(1-$ naphtylmethyl)-2-furanpropionate oxalate $5429 \mu \mathrm{g} / \mathrm{mL}$ dilarutkan dalam air dan $\alpha$ methyl- $\alpha$-propyl succinimide $3179 \mu \mathrm{g} / \mathrm{mL}$ dibuat dalam campuran air : asetonitril $(1: 1)$.

Volume contoh air disiapkan 2000 $\mathrm{ml}$ dengan melarutkan magnesium sulfat heptahydrate $238,20 \mathrm{mg}$, natrium karbonat anhydrous 210,86 mg, natrium sulfat anhydrous 570,38 $\mathrm{mg}$, kalsium khlorida dyhidrat 445,01 $\mathrm{mg}$ yang masing-masing dilarutkan dengan $80 \mathrm{ml}$ aquabides pada beaker gelas $100 \mathrm{~mL}$. Masing-masing larutan ini dimasukkan ke dalam labu takar $2000 \mathrm{~mL}$ yang telah berisi aquabides sekitar $1000 \mathrm{~mL}$ dan diaduk. Tambahkan 5 $\mathrm{mL}$ dikhloromethane sebagai pengawet dan diaduk selama 2 menit. Tambahkan $1 \mathrm{~mL}$ polyethylene glycol 200, $1 \mathrm{~mL}$ polyethylene glycol 400, 3,9 mL larutan 3,5 dihydroxytoluene, $3,7 \quad \mathrm{~mL} \quad 2-$ (diethylamino) ethyltetrahydro- $\alpha-(1-$ naphtylmethyl)-2-furanpropionate oxalate, 6,3 mL $\alpha$ methyl- $\alpha$-propyl succinimide, 4,7 mL larutan Pinacolyl methylphosphonate, 3,2 mL Triethanolamine ke dalam labu takar $2000 \mathrm{~mL}$ dan diencerkan dengan air limbah yang diambil dari tangki sebagai matriks air sampai tanda batas, dikocok selama 2 menit dan biarkan selama 24 jam. Uji kualitatif dilakukan dengan teknik GC-MS, GC-FID dan GC-FPD (P-Mode) untuk memverifikasi komposisi contoh air sebelum dimasukkan ke dalam botol masing-masing sebanyak $100 \mathrm{~mL}$.

Untuk menyiapkan blanko contoh air dilarutkan magnesium sulfat heptahydrate 238,20 mg, natrium karbonat anhydrous $210,86 \mathrm{mg}$, natrium sulfat anhydrous 570,38 mg, kalsium khlorida dyhidrat 445,01 mg yang masing-masing dilarutkan dengan $80 \mathrm{~mL}$ aquabides pada gelas kimia $100 \mathrm{~mL}$. Masing-masing larutan ini ditambahkan ke dalam labu takar $2000 \mathrm{~mL}$ yang telah berisi aquabides sekitar 1000 
$\mathrm{mL}$ dan diaduk. Tambahkan $5 \mathrm{~mL}$ dikhloromethane sebagai pengawet dan diaduk selama 2 menit dan ditanda bataskan dengan aquades.

Blanko contoh air disiapkan dengan campuran bahan kimia yang sama tanpa ada senyawa kimia berbahaya. Analisis dilakukan dengan teknik GC-MS, GC-FID dan GC-FPD (P-Mode) untuk memverifikasi bahwa larutan blanko yang digunakan tidak mengandung senyawa kimia yang akan diidentifikasi (Pinacolyl methylphosphonate dan Triethanolamine)

\section{Larutan standar senyawa kimia berbahaya}

Masing-masing larutan standar senyawa kimia berbahaya $\operatorname{Bis}(3-$ methylbutyl) ethylphosphonate, Bis(2chloroethyl) methylamine disiapkan dalam dikloromethan dan Pinacolyl methylphosphonate dan Triethanolamine disiapkan dalam asetonitril pada konsentrasi masing-msing $1 \mathrm{mg} / \mathrm{mL}$. Larutan di masukkan ke dalam vial yang ditutup rapat dan analisis dilakukan dengan GCMS, GC FID dan GC FPD (P Mode).

\section{Wadah contoh organik dan contoh air}

Contoh organik yang sudah disiapkan dipipet $10 \mathrm{~mL}$ dimasukkan ke dalam botol transparan ukuran $25 \mathrm{~mL}$ dan contoh air dipipet $50 \mathrm{~mL}$ masukkan ke dalam ke dalam botol transparan ukuran $100 \mathrm{~mL}$ dengan bahan dasar botol dari borosilikat merek Duran. Masing-masing botol dibalut dengan parafilm dan diberi label sesuai dengan kode sampel yaitu contoh organik dan contoh air.

\section{Analisis kuantitatif contoh organik}

Analisis kuantitatif dilakukan mulai dari contoh dibuat (hari ke 1) selama perioda 30 hari untuk melihat stabilitas senyawa yang diidentifikasi menggunakan teknik GC-FID/FPD. Diambil 3 contoh dengan cara acak untuk melihat homogenitas senyawa yang akan diidentifikasi. Analisis kuantitatif dilakukan pada senyawa Bis (3methylbutyl) ethylphosphonate menggunakan GC-FPD (P Mode) dan Bis(2-chloroethyl) methylamine dengan teknik GC-FID. Analisis kuantitatif dilakukan menggunakan kurva kalibrasi pada 5 titik konsentrasi yang berbeda dengan internal standar yang dilarutkan dalam asetonitril.

Tambahkan $5 \mu \mathrm{L}$ internal standar dibutyl butylphosphonate $1897 \pm 67$ $\mu \mathrm{g} / \mathrm{mL}$ ke dalam ke dalam $1 \mathrm{~mL}$ contoh organik untuk analisis Bis (3-methylbutyl) ethylphosphonate dan $5 \mu \mathrm{L}$ internal standar 2,6-dimethylphenol $1993 \pm 58 \mu \mathrm{g} / \mathrm{mL}$ untuk analisis Bis(2-chloroethyl) methylamine ${ }^{(9,10)}$.

\section{Analisis kuantitatif contoh air}

Analisis kuantitatif senyawa Pinacolyl methylphosphonate dapat dilakukan dengan menggunakan GC-FPD (P Mode) dan Triethanolamine dengan teknik GC-FID. Analisis kuantitattif dilakukan menggunakan kurva kalibrasi pada 5 titik konsentrasi yang berbeda dengan internal standar yang dilarutkan dalam asetonitril. Analisis kuantitatif senyawa Pinacolyl methylphosphonate sebelum diinjeksikan ke GC dimurnikan dengan dilewatkan ke kolom mini yang berisi penukar anion. Kolom dicuci dengan $4 \mathrm{~mL}$ aquamillipore dan $4 \mathrm{~mL}$ metanol untuk melarutkan pengotor yang terikat pada kolom mini dan dielusi dengan $2 \mathrm{~mL}$ $\mathrm{HCl} 0,1 \mathrm{~N}$ dalam metanol. Tambahkan 20 $\mu \mathrm{L}$ internal standar dibuthylphosphonate $637 \pm 24 \mu \mathrm{g} / \mathrm{mL}$ ke dalam hasil elusi. Larutan di evaporasi sampai hampir kering dan disililasi dengan menambahkan 200 $\mu \mathrm{L}$ Bis (Trimethylsilil)-trifluoroasetamida (BSTFA) dan $200 \mu \mathrm{L}$ asetonitril. Larutan dipanaskan selama 30 menit pada temperatur $60{ }^{\circ} \mathrm{C}$. Ke dalam larutan tersebut ditambahkan $600 \quad \mu \mathrm{L}$ 
dikhloromethane (total volume $1 \mathrm{~mL}$ ) dan larutan siap dianalisis dengan GC-FPD (P Mode) ${ }^{(11,12)}$.

Analisis kuantitatif senyawa Triethanolamine dilakukan dengan cara menambahkan $20 \mu \mathrm{L}$ internal standar bis(2-hydroxypropyl) $434 \pm 68 \mu / \mathrm{mL}$ yang dilarutkan dalam asetonitril, ke dalam 2,5 $\mathrm{ml}$ contoh air. Larutan dievaporasi sampai kering dan ditambahkan $500 \mu \mathrm{L}$ BSTFA untuk reaksi sililasi. Dilakukan pemanasan pada temperatur $60{ }^{\circ} \mathrm{C}$ selama 30 menit dan ditambahkan $500 \mu \mathrm{L}$ dikloromethan. Larutan siap dianalisis dengan GC-FID.

\section{HASIL dan PEMBAHASAN}

\section{Homogenitas dan Stabilitas Senyawa- Senyawa Identifikasi}

Analisis kuantitatif Bis(3methylbutyl) ethylphosphonate, $\operatorname{Bis}(2-$ chloroethyl) methylamine pada contoh organik dan Pinacolyl methylphosphonate, Triethanolamine pada contoh air dari 3 contoh yang diambil secara acak dan dianalisis secara kuantitatif untuk menentukan homogenitas dan stabilitas. Konsentrasi $(\mu \mathrm{g} / \mathrm{mL})$ rata-rata yang diperoleh dari setiap botol contoh yang dimulai dari awal contoh dibuat hingga hari ke 30. Dari analisis kuantitatif diperoleh nilai konsentrasi rata-rata, standar deviasi (SD) dan relatif standar deviasi (RSD) seperti pada Tabel 1-4. Variabilitas data-data hasil uji atau \% RSD diperoleh < $20 \%$ dan memenuhi persyaratan sebagai contoh uji profisiensi. $^{(9,12)}$

Kriteria stabilitas Bis (3methylbutyl) ethylphosphonate, Bis (2chloroethyl) methylamine pada contoh organik dan Pinacolyl methylphosphonate, Triethanolamine pada contoh air dapat dilihat dari degradasi yang dihasilkan mulai contoh dibuat sampai 30 hari masa simpan. Rentang nilai degradasi dihitung dengan nilai ketidakpastiannya pada tingkat kepercayaan $95 \%$ dengan nilai factor cakupan $(\mathrm{k})=2 .{ }^{\left({ }^{(8)}\right.}$ Degradasi yang dihasilkan dapat dilihat pada Tabel 5 dan 6.

Nilai rata-rata Bis (3-methylbutyl) ethylphosphonate, Bis (2-chloroethyl) methylamine, Pinacolyl methyl phosphonate dan Triethanolamine yang dihasilkan pada perioda waktu menentukan uji stabilitas diperoleh nilai degradasi < 30 $\%$ yang dapat dilihat dari nilai ketidakpastiannya. Contoh uji profisiensi ini adalah identifikasi bukan kuantitatif sehingga dari hasil homogenitas dengan nilai RSD < $20 \%$ dan stabilitas dengan nilai degradasinya $<30 \%$ maka contoh organik dan contoh air yang dibuat ini dapat digunakan sebagai contoh uji profisiensi yang sudah memenuhi syarat. ${ }^{(9)}$

\section{Analisis Kualitatif Contoh Organik}

Contoh organik yang ditambahkan Bis(3-methylbutyl) ethylphosphonate dan Bis(2-chloroethyl) methylamine dianalisis dengan GC-MS. Contoh dipreparasi dengan cara diekstraksi menggunakan heksan untuk memindahkan hidrokarbon yang terdapat dalam contoh dan diekstraksi kembali dengan asetonitril, larutan dievaporasi hingga volume $200 \mu \mathrm{L}$ dan larutkan hingga volume $1 \mathrm{~mL}$ dengan dikhlorometan. Larutan siap diinjeksikan ke GCMS. Senyawa Bis (3-methylbutyl) ethylphosphonate dan Bis (2-chloroethyl) methylamine memberikan waktu retensi yang sama dengan standar murni masingmasing pada waktu retensi $=16,127$ menit dan 9,753 menit dan base peak masingmasing pada $\mathrm{m} / \mathrm{z}=111$ dan 106 . Total Ion Chromatografi (TIC) dari Bis (3methylbutyl) ethylphosphonate dan Bis (2chloroethyl) methylamine dapat di lihat pada Gambar 1- 2. 
Tabel 1. Homogenitas Bis(3-methylbutyl) ethylphosphonate

\begin{tabular}{ccccc}
\hline Contoh Organik & Hari 1 $(\boldsymbol{\mu g} / \mathbf{m L})$ & Hari 7 $(\boldsymbol{\mu g} / \mathbf{m L})$ & Hari $\mathbf{2 1}(\boldsymbol{\mu g} / \mathbf{m L})$ & Hari 30 $(\boldsymbol{\mu g} / \mathbf{m L})$ \\
\hline Contoh 1 & 10,84 & 13,14 & 10,95 & 13,65 \\
Contoh 2 & 10,98 & 12,79 & 11,89 & 10,96 \\
Contoh 3 & 12,51 & 12,46 & 11,68 & 12,60 \\
Rata-rata & 11,41 & 12,80 & 11,51 & 12,40 \\
SD & 0,93 & 0,34 & 0,49 & 1,36 \\
\% RSD & 8,10 & 2,68 & 4,29 & 10,93 \\
\hline
\end{tabular}

Tabel 2. Homogenitas Bis(2-chloroethyl) methylamine

\begin{tabular}{ccccc}
\hline Contoh Organik & Hari $\mathbf{1}(\boldsymbol{\mu} \mathbf{g} / \mathbf{m L})$ & Hari $\mathbf{7}(\boldsymbol{\mu g} / \mathbf{m L})$ & Hari $\mathbf{2 1}(\boldsymbol{\mu g} / \mathbf{m L})$ & Hari 30 $(\boldsymbol{\mu g} / \mathbf{m L})$ \\
\hline Contoh 1 & 16,00 & 18,24 & 15,45 & 14,84 \\
Contoh 2 & 16,48 & 17,86 & 14,36 & 12,85 \\
Contoh 3 & 15,38 & 17,56 & 13,94 & 14,87 \\
Rata-rata & 15,96 & 17,89 & 14,58 & 14,19 \\
SD & 0,55 & 0,34 & 0,78 & 1,16 \\
\% RSD & 3,46 & 1,90 & 5,35 & 8,15 \\
\hline
\end{tabular}

Tabel 3. Homogenitas Pinacolyl methylphosphonate

\begin{tabular}{cccc}
\hline Contoh Air & Hari 0 $(\boldsymbol{\mu g} / \mathbf{m L})$ & Hari 19 $(\boldsymbol{\mu g} / \mathbf{m L})$ & Hari $\mathbf{2 9}(\boldsymbol{\mu g} / \mathbf{m L})$ \\
\hline Contoh 1 & 11,63 & 10,37 & 10,01 \\
Contoh 2 & 11,19 & 10,20 & 11,02 \\
Contoh 3 & 11,64 & 11,88 & 12,83 \\
Rata-rata & 11,48 & 10,82 & 11,28 \\
SD & 0,26 & 0,93 & 1,43 \\
\% RSD & 2,22 & 8,58 & 12,64 \\
\hline
\end{tabular}

Tabel 4. Homogenitas Triethanolamine

\begin{tabular}{cccc}
\hline Contoh Air & Hari 0 $(\boldsymbol{\mu g} / \mathbf{m L})$ & Hari 18 $(\boldsymbol{\mu g} / \mathbf{m L})$ & Hari 29 $(\boldsymbol{\mu g} / \mathbf{m L})$ \\
\hline Contoh 1 & 13,30 & 12,18 & 11,06 \\
Contoh 2 & 13,63 & 12,03 & 11,85 \\
Contoh 3 & 12,91 & 12,98 & 11,50 \\
Rata-rata & 13,28 & 12,40 & 11,47 \\
SD & 0,36 & 0,51 & 0,39 \\
\% RSD & 2,70 & 4,14 & 3,44 \\
\hline
\end{tabular}

Tabel 5. Stabilitas Senyawa-senyawa identifikasi pada Contoh Organik

\begin{tabular}{ccc}
\hline Hari ke & Bis(3-methylbutyl) ethylphosphonate & Bis(2-chloroethyl) methylamine \\
\hline 1 & $11,41 \pm 2,40 \mu \mathrm{g} / \mathrm{mL}$ & $15,96 \pm 2,70 \mu \mathrm{g} / \mathrm{mL}$ \\
7 & $12,80 \pm 1,60 \mu \mathrm{g} / \mathrm{mL}$ & $17,89 \pm 3,10 \mu \mathrm{g} / \mathrm{mL}$ \\
21 & $11,51 \pm 2,51 \mu \mathrm{g} / \mathrm{mL}$ & $14,58 \pm 2,80 \mu \mathrm{g} / \mathrm{mL}$ \\
30 & $12,40 \pm 2,40 \mu \mathrm{g} / \mathrm{mL}$ & $14,19 \pm 3,0 \mu \mathrm{g} / \mathrm{mL}$ \\
\hline
\end{tabular}

Tabel 6. Stabilitas Senyawa-senyawa identifikasi Contoh Air

\begin{tabular}{ccc}
\hline Hari ke & Pinacolyl methylphosphonate & Triethanolamine \\
\hline 0 & $11,41 \pm 1,48 \mu \mathrm{g} / \mathrm{mL}$ & $13,28 \pm 2,23 \mu \mathrm{g} / \mathrm{mL}$ \\
19 & $10,82 \pm 2,20 \mu \mathrm{g} / \mathrm{mL}$ & $12,40 \pm 2,40 \mu \mathrm{g} / \mathrm{mL}$ \\
29 & $11,28 \pm 2,78 \mu \mathrm{g} / \mathrm{mL}$ & $11,47 \pm 2,17 \mu \mathrm{g} / \mathrm{mL}$ \\
\hline
\end{tabular}




\section{Analisis Kualitatif Contoh Air}

Senyawa - senyawa yang diidentifikasi pada contoh air yaitu Pinacolyl methylphosphonate dan Triethanolamine dianalisis dengan GCMS. Analisis kualitatif Pinacolyl methylphosphonate dipreparasi terlebih dahulu dengan dipipet $5 \mathrm{~mL}$ contoh air dan dievaporasi. Tambahkan $0,5 \mathrm{~mL}$ BSTFA dan $0,5 \mathrm{~mL}$ asetonitril, dipanaskan pada temperatur $60{ }^{\circ} \mathrm{C}$ selama 30 menit untuk proses sililasi. Hasil sililasi disaring dengan menggunakan pipet tip yang diisi kapas dan tambahkan 0,5 mL dikhlorometan. Larutan siap diinjeksikan ke GCMS.

Analisis kualitatif senyawa Triethanolamine dilakukan dengan cara mepipet $2 \mathrm{~mL}$ contoh air, dimurnikan dari pengotor dengan melewatkan ke kolom mini yang berisikan penukar anion yang terlebih dahulu dikondisioning dengan 1 $\mathrm{mL}$ metanol dan $1 \mathrm{~mL}$ aquamillipore.
Kolom dicuci dengan $4 \mathrm{~mL}$ aquamillipore dan $4 \mathrm{~mL}$ metanol, dielusi dengan $2 \mathrm{~mL}$ $0,1 \mathrm{~N} \mathrm{HCl}$ dalam metanol dan hasil elusi dievaporasi sampai hampir kering dengan mengalirkan gas nitrogen. Residu disililasi dengan menambahkan $200 \mu \mathrm{L}$ asetonitril dan $200 \mu \mathrm{L}$ BSTFA. Sililasi dilakukan pada temperatur $60{ }^{\circ} \mathrm{C}$ selama 30 menit dan tambahkan $600 \mu \mathrm{L}$ dikhlorometan dan injeksikan ke GCMS. Senyawa Pinacolyl trimethylsilyl methylphosphonate yang merupakan hasil sililasi memberikan waktu retensi yang sama dengan sililasi standar murni pada waktu retensi $=13,017$ menit dengan base peak pada $\mathrm{m} / \mathrm{z}=163$ sedangkan hasil analisis kualitatif senyawa hasil sililasi Tris (trimethylsilyloxyethyl) amine memberikan waktu retensi yang sama dengan sililasi standar murni pada waktu retensi $=17,045$ menit dengan base peak pada $\mathrm{m} / \mathrm{z}=262$. Total Ion Chromatografi (TIC) dari Pinacolyl methylphosphonate dan Triethanolamine dapat dilihat pada Gambar 3-4.
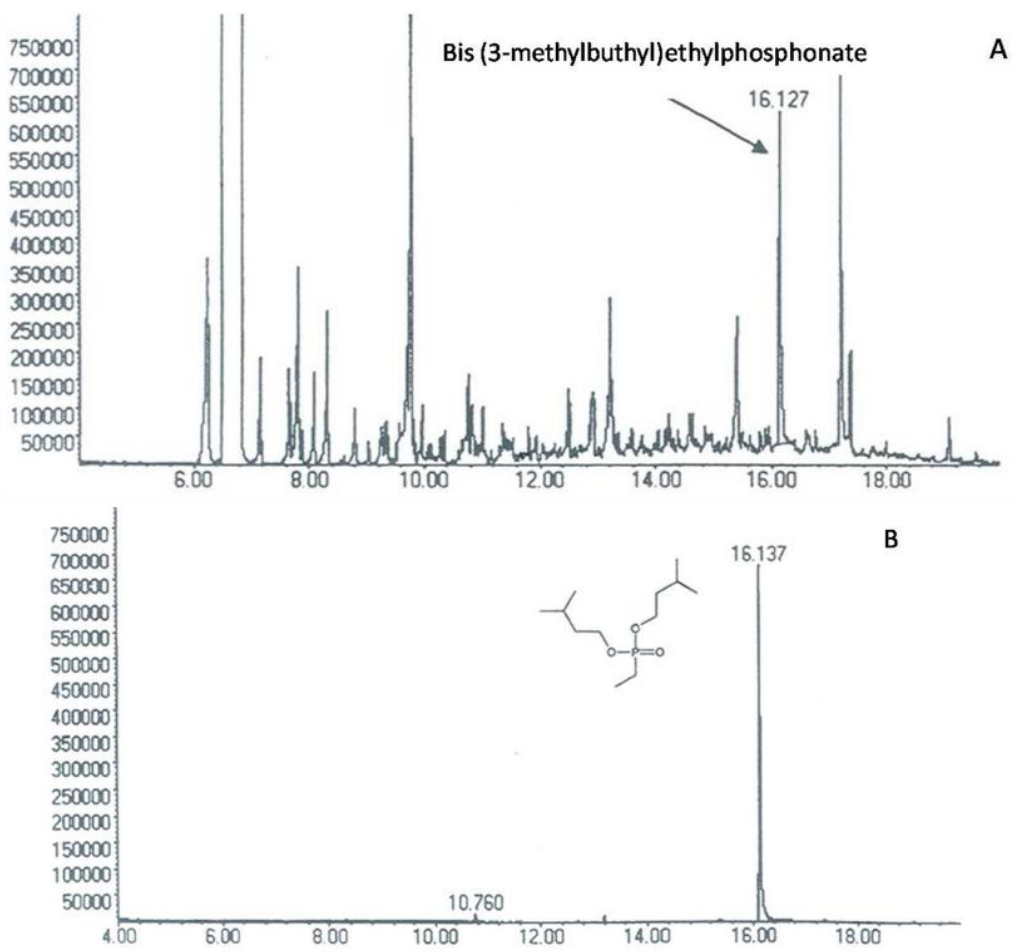

Gambar 1. Total Ion Chromatography. $A=$ contoh, $B=$ Standar 

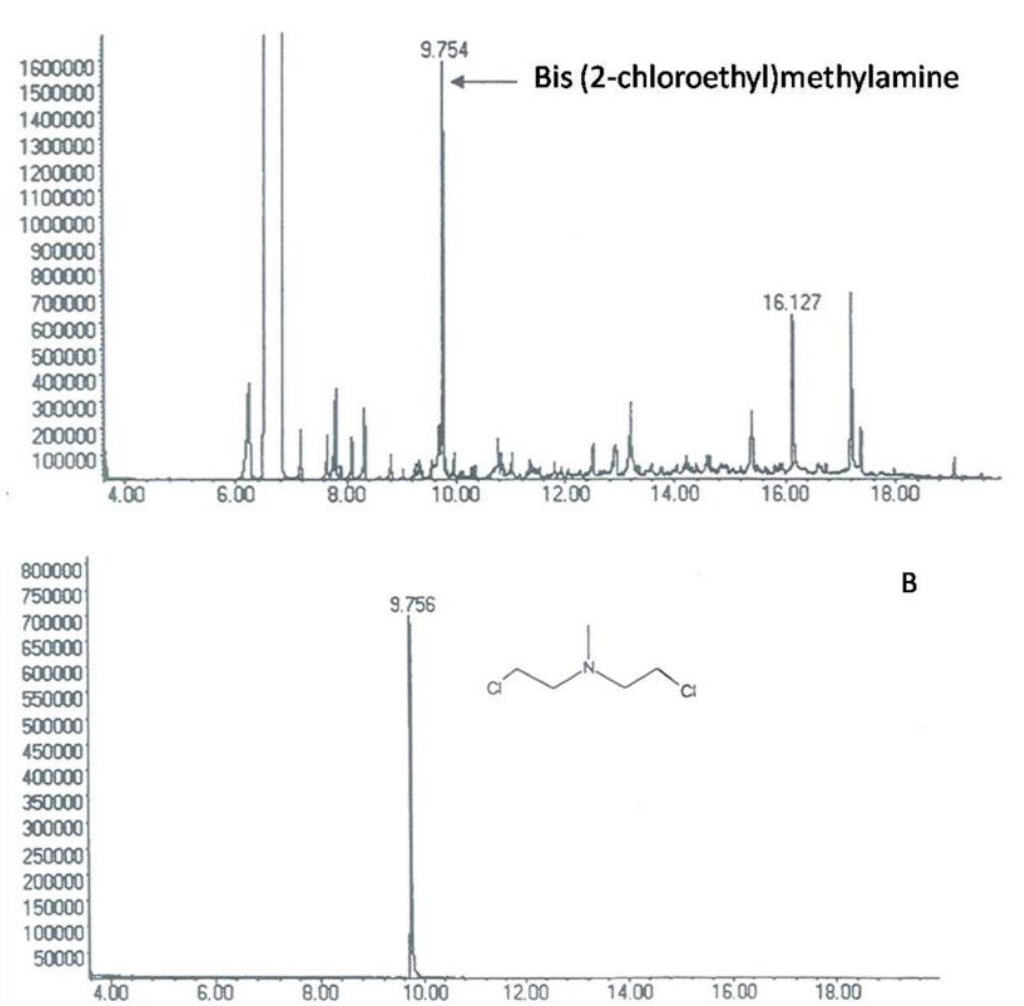

A

Gambar 2. Total Ion Chromatography. A= contoh, B = Standar

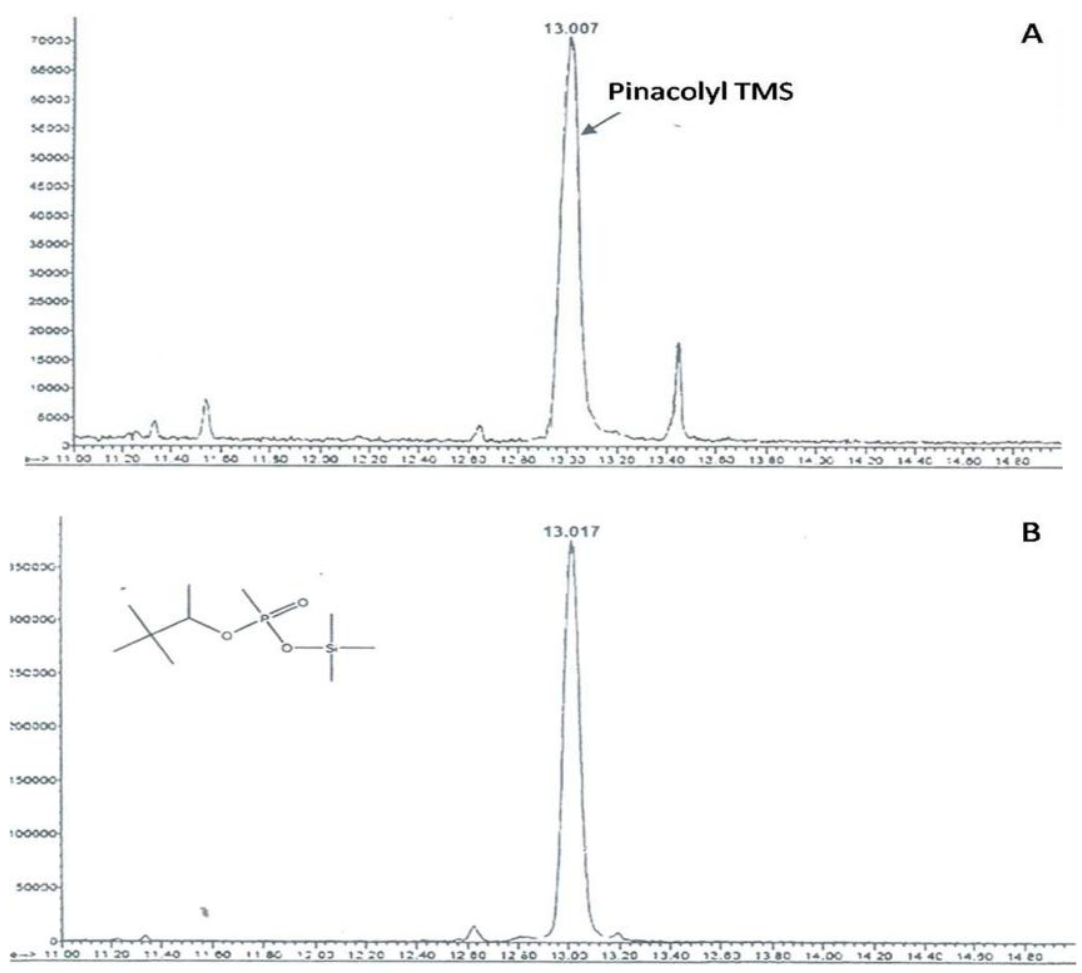

Gambar 3. Total Ion Chromatography. $A=$ contoh, $B=$ Standar 

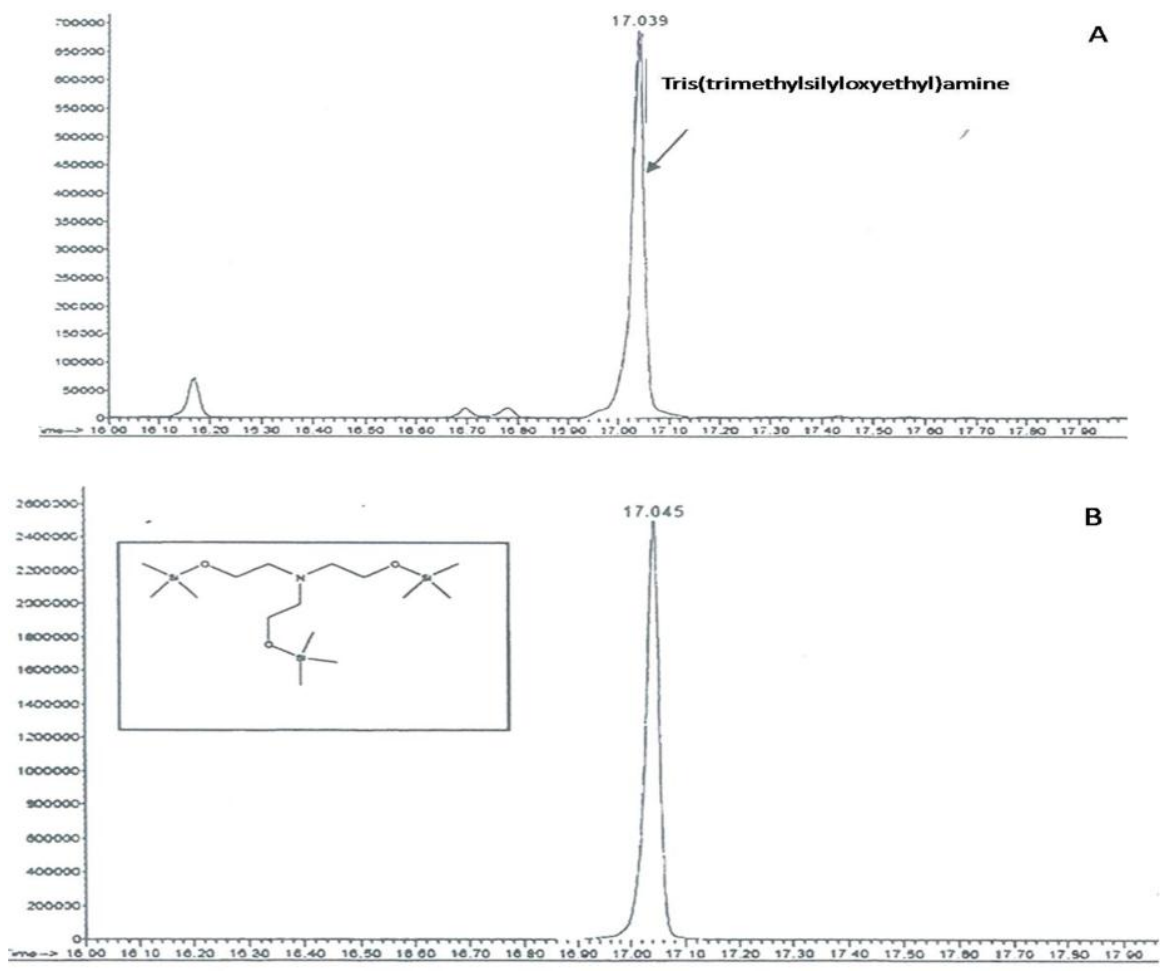

Gambar 4. Total Ion Chromatography. A= contoh, B = Standar

\section{KESIMPULAN}

Contoh organik dan contoh air uji profisiensi dapat dibuat dari matrik organik (buangan limbah organik) dan matriks air (buangan limbah air) dengan menambahkan bahan-bahan pengganggu yang mempunyai sifat kimia non polar pada contoh organik dan sifat kimia polar pada contoh air. Senyawa yang diidentifikasi Bis (3-methylbutyl) ethylphosphonate, Bis (2-chloroethyl) methylamine, Pinacolyl methylphosphonate dan Triethanolamine ditambahkan pada masing-masing matrik.

Contoh uji profisiensi baik yang organik maupun air dilakukan uji homogenitas dan stabilitas dengan cara analisis secara kuantitatif menggunakan teknik GC-FID dan GC-FPD (P-Mode). Diperoleh contoh uji profisiensi yang homogen dengan nilai RSD yang dihasilkan dibawah $20 \%$ dan stabil dengan nilai degradasi dibawah dari $30 \%$.
Uji kualitatif dilakukan baik dengan GC-FPD (P-Mode), GC-FID dan GCMS. Diperoleh Bis (3 - methylbutyl) ethylphosphonate dan Bis (2-chloroethyl) methylamine dengan base peak masingmasing pada $\mathrm{m} / \mathrm{z}=111$ dan 106 yang sesuai dengan senyawa murni sedangkan Pinacolyl trimethylsilyl methylphosphonate dan Tris (trimethylsilyloxyethyl)-amine dengan base peak masing-masing pada $\mathrm{m} / \mathrm{z}=163$ dan $\mathrm{m} / \mathrm{z}=262$ yang sesuai dengan senyawa murni.

\section{DAFTAR PUSTAKA}

1. Kruger Sabine. On Site Analysis by the Inspection Team, Sampling, Analysis, Equipment, Procedures and Strategies. 2005, pp 33-64

2. W.P. Cofino, Accreditation and Interlaboratory Studies, Accreditation and Quality Assurance in Analytical Chemistry, 1994. 
3. John Gilbert et. al. Pure\&appl. Chem, Vol 70, No 12, pp. 2309-2312 (1998)

4. ISO IEC 17043: 2010 General Requirements for Proficiency Testing

5. EURACHEM Guide, Selection, Use and Interpretation of Proficiency Testing (PT) Scheme. 2nd ed. 2002.

6. Standar Operating Procedure for Proficiency Test, QDOC/LAB/SOP/PT 2014

7. Michael Thompson et.al. Pure appl. Chem, Vol 78, No 1, pp. 145-196 (2006)

8. Work Instruction for Preparation of Test Samples for Proficiency Tes, QDQC/LAB/WI/PT02, 2014

9. Jeanet Hendrikse, A Comprehensive Review of the Official OPCW Proficiency Test, 2005, pp 89-127

10. Marja-Leena Kuitunen,. Sample Preparation for Analysis of Chemicals Related to the Chemical Weapons Convention in an Off-site. 2005, pp. 163-180,

11. EURACHEM/CITAC Guide, Quantifying Uncertainty in Analytical Measurement, 3rd ed, 2012,.

12. W.P. Cofino, Accreditation and Interlaboratory Studies, Accreditation and Quality Assurance in Analytical Chemistry, Springer-Verlag, Berlin Heidelberg, New York, 1994 
JKTI, Vol. 17, No. 1, Juni 2015 